\title{
Natural transitions: from K-12 to US academic library instructors
}

\author{
Antonia P. Olivas
}

\author{
Information Literacy/Research Help Department, California State University, \\ San Marcos, San Marcos, California, USA
}

\begin{abstract}
Purpose - The purpose of this paper is to investigate the decision of former traditional K-12 teachers in the USA who chose a new career path in academic libraries. It focuses on their successes and challenges in higher education settings.

Design/methodology/approach - This study uses a qualitative-methods approach which includes a brief questionnaire.

Findings - Findings indicate that former K-12 teachers leave their traditional teaching professions due to bureaucracy but because they enjoy teaching, they seek other opportunities in education. The research also reveals that many of the participants continue to use their $\mathrm{K}-12$ training in their current instruction positions as academic librarians.

Research limitations/implications - Future research on this topic should look into more proactive ways of recruiting K-12 teachers into positions of information literacy instructor in academic libraries.

Practical implications - Those responsible for hiring information literacy instruction librarians will learn the benefits of hiring former K-12 teachers. The paper will also help encourage academic library leaders to help fund more training opportunities for information literacy librarians.

Social implications - All around the USA, academic libraries are fostering opportunities for their students to become information literate in the hopes of helping students succeed in college-level research. As more former K-12 teachers are hired in higher education academic instruction librarian positions, it could help students make a smoother transition from high school to college-level researchers. Originality/value - This research shows that former K-12 teachers could be a valuable asset to higher education academic libraries. Keywords Academic libraries, Library instruction, Information literacy, Instruction librarian, Teachers, K-12, Career change, United States of America

Paper type Research paper

\section{Introduction}

Information literacy (IL) is the foundation for college-level research and is in higher demand today than it was just five years ago. In addition to possessing various other skills such as the ability to work closely with university faculty; serve on national, international, and campus committees; and produce high quality research, many academic librarians are expected to teach some version of IL on the job (Chandrasekhar, 2002; Thompson, 2002). As far back as the early 1990s reference librarian jobs began including instruction as a part of their job duties (Lynch and Smith, 2001). Whether IL sessions are one-shots or for-credit courses, instruction librarians are on the frontlines when it comes to teaching college students these valuable information seeking skills to help prepare them for their academic futures. Librarians from all backgrounds are developing the teaching skills needed to teach these IL courses successfully, so it may be appropriate to recruit university instruction librarians from school environments who serve children from kindergarten through to 12 th grade (K-12) - typically these students range from five years old all the way up to 18 years of age). Teachers who work in these traditional K-12 environments have been trained in various classroom management styles and lesson planning techniques. And those who have an education background seem to thrive in these IL teaching environments, so it may be time to actively recruit university instruction librarians from K-12 environments.

This paper in no way implies that K-12 teachers are better than or somehow lesser than other academic librarians who teach IL courses and do not have a bachelor's degree in K-12 education. The purpose of this study is to show the natural transitions between the instruction training received in a K-12 environment and the skills needed to teach IL on college/university campuses. The author fully recognizes that not all $\mathrm{K}-12$ trained teachers will fit in a college/university setting. Moreover, library instructors from other backgrounds (non K-12 trained) are some of the top IL instruction librarians in the USA. This paper is written with the understanding that although K-12 trained teachers may possess the knowledge, skills and abilities to perform highly in traditional K-12 classrooms, due to the culture of higher education, a K-12 trained person will have to make the necessary adjustments needed to help them transition into college or university level instruction.

This study looks at the current landscape of literature on library school curriculum and how this prepares future librarians who will be teaching college/university IL courses. It then looks at the struggles traditional teachers face in their K-12 teaching environments and discusses the reasons why these individuals quit and where they traditionally end up. All of this sets the stage for the current study and how academic libraries can use this information to their advantage in recruiting former K-12 teachers.
\end{abstract}




\section{Literature review}

\section{IL in LIS curriculum}

A study looked at 93 library school programs' curricula to see how many of them offered courses in IL and found that "a majority of the schools (51.6 percent, $n$ 1/4 48) appear to offer no course in information literacy instruction" ( Julien, 2005, p. 213). It was difficult to find a more current study on the number of LIS schools that offer IL. As initiatives to include IL into higher education curricula increases, the knowledge, skills and abilities of teaching librarians able to not only teach the material but to manage the classroom is becoming increasingly important for academic libraries. Unfortunately, as Hook et al. (2003) express, "there are limited teaching assistantships for students enrolled in MLIS programs and instruction courses are either not offered or offered infrequently". With nearly half of the teaching workforce of the USA quitting their traditional K-12 careers and an expected 45 percent of academic librarians reaching the age of 65 or older this decade (Lynch et al., 2002), there is an immediate opportunity to recruit new librarians, particularly within the field of IL.

In order to be effective IL librarians, these specialists need skills in classroom management, lesson planning, "faculty negation and outreach, learning theory, and designing active assignments that meet immediate needs and promote lifelong learning" (Albrecht and Baron, 2002, p. 73). According to Hook et al. (2003) library school education does not properly prepare new librarians to teach IL. In a 2002 survey conducted by Albrecht and Baron (2002, p. 141), the authors found that many instruction librarians did not feel they acquired sufficient (if any) instruction training in library school so they rely on workshops and on the job training. Training new librarians in IL is a huge responsibility in and of itself, but Hook et al. (2003, p. 102) add that changing university environments require all instructional librarians to update their teaching skills and to be aware of their approaches to teaching, "such changes include developing and assessing learning outcomes, delivering scalable instruction, and staying abreast of new technologies that impact instructional design". The authors described a series of workshops at the University of Arizona that provides in-house training to all of their IL librarians. The participants of these workshops were able to analyze faculty assignments, identify the IL skills students would need in order to complete them, and assess the students' learning through "individual, formative assessments" (Hook et al., 2003, p. 109). This article did mention that not all teaching librarians participated in these voluntary workshops; therefore, they felt they did not achieve their goal of establishing a foundation of skills and understanding of teaching IL (Hook et al., 2003, p. 117).

A 2009 study examined the curriculum of 49 library schools around the world and identified 59 qualifications that were essential for graduation in library science. The study found that IL is not documented as a skill or qualification but instead, much like "knowledge management" or "scholarly communication", it is viewed more as a generic field of practice for a librarian (Gerolimos, 2009, p. 536). Could this be why so many librarians are learning their IL skills on the job? Even international studies have found that although many of their library school curriculums are not teaching IL, it is still a skill librarians need to survive in their jobs. Parry (2008, p. 46) looked at the life cycle of English academic librarians from library school all the way through recruitment and performance and found that in addition to developing expertise in emerging technologies and research skills, librarians need to be familiar with pedagogic skills and IL.

International institutions such as City University London (Robinson and Bawden, 2010) discuss changes to their core curriculum which include IL, and a recent study on 11 Australian university and vocational LIS programs recommends adding more IL instruction to their curriculum (Partridge and Yates, 2012). This researcher was unable to find more recent studies on the redesign of the LIS curriculum in the USA which specifically focus on the inclusion of robust IL courses. However, there were a few studies that focused on evaluating current IL programs in colleges and universities, but those studies did not mention the design or evaluation of IL courses in LIS programs (Dickson, 2004; Spackman, 2007). Nor is there any mention of IL in The Standards for Accreditation of Master's Programs in Library \& Information Studies (ALA, 2008) or the Guidelines for Professional Library/Information Educational Programs (IFLA, 2012).

Librarians entering the field who are interested in becoming IL instruction librarians are therefore learning

their valuable skills on the job. These librarians master these skills and are delivering high quality IL courses to their students. If library schools are continuing to deny access to IL in their curriculum, one way around this issue is to recruit former K-12 classroom teachers who have already been trained in the skills needed to become IL library instructors.

\section{Why do teachers quit?}

An estimated 50 percent of new teachers quit within five years of entering the classroom (Hunt and Carroll, 2003). The reason for this is often cited by teachers as a lack of support and poor working conditions (Alliance for Excellent Education, 2005; Brownell et al., 1997). New teachers are particularly vulnerable to quitting because they 
are more likely to be assigned low-performing students in their classrooms. Despite the added challenges that come with teaching low-performing or under-achieving students, most new teachers are given little professional support and are stressed by administrative duties test scores (Alliance for Excellent Education, 2005).

The percentage of teachers abandoning the classroom for other careers continues to grow. However, evidence suggests that very few teachers leave the profession for higher paying jobs. In a 2006 study on Georgia teachers, Scafidi et al. (2006, p. 2) found that some of their teachers took a non-education sector job that paid more. They discovered that while 12.1 percent of teachers who left the profession reported that the main reason for leaving was to pursue another career, only 6.5 percent reported that they left for better salary or benefits (Scafidi et al., 2006, p. 30). Other research shows that teachers leave for reasons beyond pay. According to Palmer (2007), for example, 64 percent of the former teachers who left traditional K-12 settings said they have more professional autonomy in their new professions than when they taught K-12.

The US Department of Education (2011) produced a report based on public and private K-12 school teachers that follow up on the 2008-2009 teacher follow-up survey (TFS). The purpose of the questionnaire was to obtain information about teachers who left the classroom, such as information about their present occupation, reasons for leaving teaching, comparison of current position to teaching, and demographic characteristics that might have changed since the previous year. This study found that most teachers who leave the traditional K- 12 classroom end up in other areas of education. If former teachers are staying in the field of education but not in traditional K-12 classrooms, why are not more of them recruited to positions of academic library instruction? They already have the pedagogical theories of learning and the understanding of classroom management; using their skills in a university IL environment makes sense.

\section{Where do they go?}

Often these former teachers find jobs outside a traditional K-12 classroom. According to Brownell et al. (1997), a number of special education teachers, for example, find themselves in administrator positions or in charter schools where they do not deal with the bureaucracy. They specifically interviewed 93 former special education teachers at random to determine what occupations they pursued after leaving their K-12 classrooms. Their study found that a majority of their respondents left the special education classroom for general education classrooms; others left to be administrators or district-level specialists.

In 2005 Johnson, Berg and Donaldson researched the potential of recruiting retired teachers as volunteers in K-12 classrooms to help new teachers. These retired teachers bring additional skills and experiences to the classroom, particularly in the area of behavior and classroom management. Johnson et al. (2005) also stress that nearly half of the teaching workforce is expected to retire this decade; presenting an immediate opportunity to recruit these former teachers into academic library IL positions.

\section{Statement of the problem}

This research will reveal several factors generated by individuals' prior experiences that contribute to the K-12 transition into higher education libraries. Many of these factors correspond with prior research that has detailed K-12 teacher motivation for leaving the traditional classroom setting all together. Later discussion will show other factors that appear unique to these career changers whose stories share additional complexities leading to their current circumstances in academic libraries.

\section{Methods}

In order to understand better the factors leading to former K-12 teachers' current library career choice, a questionnaire was sent out to several listserves. This approach helped chronicle individual participant's transitions into librarianship and examined how their past experiences as K-12 teachers related to their current positions as IL professionals in academic library settings. This form of analysis reveals career successes, lessons learned, and turning point moments the individual chooses to include. Analyzing these questionnaire answers gives significant insight into the minds of former traditional classroom teachers and how they made the transition into higher education IL programs. Using data gathered from this questionnaire, this researcher asked participants to share their stories through their responses to open-ended questions which focused on each individual's career decision.

\section{Results and discussion}

Two hundred six participants responded to the online questionnaire, but 13 participants were disqualified after answering No to the first question: "Are you currently an academic librarian at a college or university?" Of the remaining 193 participants, 60 answered Yes to the second question: "Did you receive a K-12 teaching certificate or 
bachelor's degree in education?" The questionnaire did not specifically ask if participants were ever K-12 school media specialists, although that information would have been helpful.

The remainder of the questions focused on time spent in the K-12 environments and factors that contributed to their second career choice as a librarian. A majority of these participants were in K-12 environments for less than five years (13.5 percent - less than one year; 42.2 percent - one to five years). When asked if the participants were current IL (teaching) librarians, 90.2 percent of respondents answered Yes to the question.

The questionnaire asked participants to briefly explain the factors leading to a decision to pursue a second career in library and information science, many of the respondents indicated that stress from standardized testing and overall dissatisfaction with traditional K-12 teaching environments were the leading cause of why they left teaching:

No Child Left Behind test-driven education changes to curriculum so there is less funding for arts, less emphasis on creativity, debate, and divergent thinking.

As an English teacher in a public high school, I had no personal life for 10 months out of the school year - I was always prepping, teaching, grading, and prepping. I became an "accidental" high school librarian and realized it supplied me with the best parts of being an educator-building relationships, instilling knowledge, interacting creatively with information-but allowed for personal downtime on evenings and weekends.

Quite a few of the concurring respondents wanted to get away from the pressures of grading or simply stated they had "professional burnout" from traditional K-12 teaching. Some participants stated they were disappointed with salaries or simply did not enjoy teaching specific grade levels. A sampling of these answers ranged from "Did not like teaching high school" or "I'm not very good with children" to "I wanted to work with smaller groups and individuals rather than with classrooms. I also felt I could do more good focusing on connecting people with information rather than trying to 'teach' a mandated curriculum".

Surprisingly, many of the respondents stated that librarianship was always a part of their career path but for various reasons they decided to start in K-12 settings first. Some of those reasons included: "Always wanted to become a librarian but was advised by a counselor to go into teaching" and "My career choice was librarian but went to teacher's college because it was my parents' choice".

Other factors that contributed to becoming a librarian and leaving teaching included "British teaching degree not recognized in the state of [omitted for anonymity]" and location of family in regards to teaching position. Many of the respondents were once paraprofessionals when they were earning their teaching degrees or soon after receiving their teaching degrees and decided to go back to library school to earn their MLIS and get a job in libraries:

The school I worked in was an alternative and didn't pay much. I took a library assistant job to make ends meet and decided to stay in libraries.

I was a stay at home mother for years and when I wanted to return to work, my husband and I talked about what it was I enjoyed the most: teaching and my library work in college and as a school volunteer.

Had worked student jobs in library, had a librarian mother, and hated teaching middle school.

I had a position as a high school English teacher and part-time high school librarian.

I had already worked in an academic library curriculum resource center as a support staff person. So I returned to school to get my MLS so that I could eventually move into a leadership position.

The two questions that were the main focus of this research were in regards to the type of K-12 training participants had and how (if at all) that training helped them in their current positions. Respondents were asked to be as detailed as possible in their responses.

When asked how their time and training as a $\mathrm{K}-12$ teacher helped in their current IL/instruction position with college/university students, one respondent stated that the time spent in a K-12 environment has not helped with IL in academic libraries. However, the rest of the librarians stated their training as K-12 teachers helped them tremendously in libraries because they were already familiar with learning and teaching theories, lesson planning, and classroom management. They stressed that they felt more comfortable analyzing the needs of their students, developing and achieving student learning outcomes, developing rubrics, and implementing instructional design principles: 
I thought my training as a K-12 teacher was invaluable in giving me the pedagogical knowledge to design effective library instruction for university students. It also helped me immensely with learning how to deal with the public at the reference desk and to provide instruction at the reference desk.

The experience that I had working in the K-12 environment has provided me with a wealth of instructional tools that can easily be adapted to the college-level instructional setting. Because I have taught students at all levels, I have a much better understanding of how to explain concepts, ideas, and jargon to incoming freshmen while still providing higher-level content and instruction to those at the graduate level.

As a K-12 teacher I learned how to create lesson plans, find creative way to present material, assess student learning, and assume the identity of teacher. That has never left me even as a librarian.

Meeting students at their level of development was important and remains part of my philosophy. Just because I work with adults, I do not assume they "know" how to do research or write a paper. Also, teaching techniques/methodology/pedagogy is widely discussed and emphasized in K-12. That has helped me articulate some of the challenges teaching at the college level.

The instructional skills I honed as a K-12 teacher inform my daily practice as an academic librarian. I also know where my college students have come from, and thus can work with them at a more appropriate developmental level.

When asked how library school helped prepare them for IL instruction in a higher education environment, nearly all respondents stated they received little to no training in regards to IL. The instruction that was received included becoming familiar with the ACRL standards and practicing one-shot bibliographic instruction. One participant stated s/he trained to be a school librarian and was always encouraged to include the library into the curriculum. This person's library school prepared them with requiring them to give plenty of class presentations and learning how to operate audio visual equipment. This person was part of a program that offered internship opportunities.

Another respondent stated s/he had a course with a library instructor who required them to give presentations on subjects of their choice. Although this provided some form of instruction training, it also showed "poor examples of teaching!" For the most part, most respondents stated they continued their instruction education training through LOEX conferences, webinars, constant practice and observations:

My undergraduate education degree and experience and on the job training did.

My library degree did not adequately prepare my classmates for this. We did learn how to create pathfinders, which seems to (even now) be the preferred method of gathering information resources for users, i.e. LibGuides.

The MLIS program I attended offered a single course in information literacy instruction, which I dutifully completed, but I gained more experiential knowledge from credential course work, classes completed in earning my Master's in Teaching, and professional development seminars. This *despite * the fact that the Information Studies department at my alma mater was conjoined with the university's Education department. The university missed a tremendous opportunity to offer cross-curricular programming of direct relevance to school and college librarians - a loss I find perennially tragic.

\section{Conclusion}

Although librarians with previous K-12 training bring with them specific teaching methods and classroom management skills that may help them transition easier into an academic library teaching setting, it is important to stress that having a K-12 background does not automatically make a person a natural or even a good library instructor. Having this background merely gives an instruction librarian an advantage when first entering a library classroom. Whether teaching one-shots or longer IL courses, instruction librarians from all backgrounds are credited with teaching and developing the skills needed for students to successfully complete their college-level research assignments. Until the LIS curriculum is aligned to include robust instruction/teaching courses, librarians who do not have the K-12 training will be required to seek out their own forms of instruction training. In addition to having an interest in teaching and a passion for helping college students, any librarian interested in working in an IL environment should be given the opportunity to develop and enhance his/her instruction through conferences such as LOEX or be given an opportunity to participate in teaching fellowships.

\section{References}

ALA (2008), Standards for Accreditation of Master's Programs in Library \& Information Studies, 
Available at:

www.ala.org/accreditedprograms/sites/ala.org.accreditedprograms/files/content/standards/standards_2008.pdf

Albrecht, R. and Baron, S. (2002), "The politics of pedagogy: expectations and reality for information literacy in librarianship", Journal of Library Administration, Vol. 36 Nos 1/2, pp. 71-96.

Alliance for Excellent Education (2005), Teacher Attrition: A Costly Loss to the Nation and to the States, Issue Brief, available at: www.all4ed.org/files/archive/publications/TeacherAttrition.pdf (accessed 8 October 2012).

Brownell, M.T., Smith, S.W., McNellis, J.R. and Miller, M.D. (1997), “Attrition in special education: why teachers leave the classroom and where they go", Exceptionality, Vol. 7 No. 3, pp. 143-155, available at: http://web.ebscohost.com/ehost/pdfviewer/pdfviewer?vid 1/44\&hid1/4105\&sid1/4571f6ad75bea40b7b600d6fe7c838a92\% 40sessionmgr113 (accessed 8 October 2012).

Chandrasekhar, R. (2002), “Teaching information literacy”, Bridgewater Review, Vol. 21 No. 2, pp. 10-11, available at: http://vc.bridgew.edu/br_rev/vol21/iss $2 / 6$

Dickson, V. (2004), "Collaboration plus! The development of an information literacy and communication program", Australian Library Journal, Vol. 53 No. 2, pp. 153-160.

Gerolimos, M. (2009), "Skills developed through library and information science education”, Library Review, Vol. 58 No. 7, pp. 527-540.

Hook, S.J., Bracke, M., Greenfield, L. and Mills, V.A. (2003), "In-house training for instruction librarians”, Research Strategies, Vol. 19 No. 2, pp. 99-127.

Hunt, J. and Carroll, T. (2003), "No dream denied: a pledge to America's children", Summary Report of National Commission on Teaching and America's Future, Education Commission of the States, Washington, DC, available at: www.ecs.org/html/Document.asp?chouseid1/44269 (accessed 8 October 2012).

IFLA (2012), Guidelines for Professional Library/Information Educational Programs, available at: www.ifla.org/files/assets/set/publications/guidelines/Guidelines\%202012_revision_SET\%20FINAL\%202012.pdf

Johnson, S.M., Berg, J.H. and Donaldson, M.L. (2005), Who Stays in Teaching and Why: A Review of the Literature on Teacher Retention, NRTA Educator Support Network, available at: http://assets.aarp.org/www.aarp.org_/articles/NRTA/Harvard_report.pdf

Julien, H. (2005), "Education for information literacy instruction: a global perspective", Journal of Education for Library and Information Science, Vol. 46 No. 3, pp. 210-216, available at: www.jstor.org/stable/40323845

Lynch, B.P. and Smith, K.R. (2001), "The changing nature of work in academic libraries", College\& Research Libraries, Vol. 62 No. 5, pp. 407-420, available at: http://crl.acrl.org/content/62/5/407.full.pdfphtml.

Lynch, M.J., Tordella, S. and Godfrey, T. (2002), Retirement \& Recruitment: A Deeper Look, American Library Association: Librarianship \& Library Staff Statistics, available at: www.ala.org/ala/research/librarystaffstats/recruitment/recruitretire-adeeperlook.pdf

Palmer, K. (2007), "Why teachers quit", Teacher Magazine, Vol. 18 No. 6, p. 45, available at: www.google.com/url?sa1/4t\&source $1 / 4$ web \&cd $1 / 44 \&$ ved $^{1} / 40 C C s Q F j A D \& u r l 1 / 4 h t t p \% 3 A \% 2 F \% 2 F 216.78 .200 .159 \% 2 F D o$ cuments\%2FRandD\%2FOther\%2FWhy\%2520Teachers\%2520Quit.doc\&rct $1 / 4 \mathrm{j} \& \mathrm{q}^{1} / 4$ why $\% 20$ teachers\%20quit $\% 20$ palm er\&ei1/4SbHvTfPhDsTZiALYuLH1AQ\&usg1/4AFQjCNGgQGQPVeVTo6FLR7YpfaLN9xOC7Q

Parry, J. (2008), “Librarians do fly: strategies for staying aloft”, Library Management, Vol. 29 No. 1, pp. 41-50.

Partridge, H.L. and Yates, C. (2012), "A framework for the education of the information professions in Australia”, Australian Library Journal, Vol. 61 No. 2, pp. 81-94.

Robinson, L. and Bawden, D. (2010), "Information (and library) science at City University London; 50 years of educational development", Journal of Information Science, Vol. 36 No. 5, pp. 631-654. 
Scafidi, B., Sjoquist, D.L. and Stinebrickner, T. (2006), "Do teachers really leave for higher paying jobs in alternative occupations?", Advances in Economic Policy, Vol. 6 No. 1, pp. 1-42, available at:

www.gppf.org/pub/education/advances.pdf

Spackman, E. (2007), "Utilizing focus groups to evaluate an information literacy program in a general biology course", Science and Technology Libraries, Vol. 27 No. 3, pp. 3-28, available at: http://pubget.com/paper/pgtmp_ee651fb57dfec217f99d0ecd4fefbffa/Utilizing_Focus_Groups_to_Evaluate_an_Informa tion_Literacy_Program_in_a_General_Biology_Course

Thompson, G.B. (2002), "Information literacy accreditation mandates: what they mean for faculty and librarians", Library Trends, Vol. 51 No. 2, pp. 218-241, available at: http://ezproxy.csusm.edu/login?url1/4http://search.ebscohost.com/login.aspx?direct $1 / 4$ true \&db1/4aph\&AN1/49031050\&sit $\mathrm{e}^{1 / 4}$ ehost-live

US Department of Education (2011), Documentation for the 2008-09 Teacher Follow-up Survey, National Center for Education Statistics, available at: http://nces.ed.gov/pubs2011/2011304.pdf 